\title{
Hepatic Glucokinase Activity and Circulating Insulin Concentrations in Two Inbred Mouse Strains
}

\author{
F. L. Lavender, P. A. James and D. G. Walker \\ Department of Biochemistry, University of Birmingham, UK
}

\begin{abstract}
Summary. Hepatic glucokinase activity in the $\mathrm{C} 3 \mathrm{H} / \mathrm{He}$ strain of mice is about twice that in the C58 strain. Genetic analysis of hybrids and back-crosses indicates control of activity by a single codominant gene. The adaptations of activity that occur when animals of the two strains are starved, fed a carbohydrate-free diet or made streptozotocin-diabetic are similar in the two strains. In almost all the situations tested, plasma insulin concentrations were higher in the $\mathrm{C} 3 \mathrm{H} / \mathrm{He}$ strain than in the $\mathrm{C} 58$ strain. On the assumption that insulin plays some role in the synthesis of glucokinase, the possible association be-
\end{abstract}

tween the plasma insulin concentration and hepatic glucokinase activity in mice in which plasma glucose concentrations are similar is discussed. The twofold difference in glucokinase activity between the two strains is associated with only minor differences in glucose tolerance and insulin response to a glucose load.

Key words: Hepatic glucokinase activity, genetic control of enzyme activity, plasma insulin, plasma glucose, streptozotocin sensitivity, inbred mouse strains.
Glucokinase (EC 2.7.1.2) is the principle glucose-phosphorylating enzyme in the liver parenchymal cells of many species and has properties that equip it to fulfil a unique role in the regulation of hepatic glucose utilization $[1,2]$. Most studies on the enzyme and its regulation have used the rat. In that species glucokinase, which has a $\mathrm{K}_{\mathrm{m}}$ of about $5 \mathrm{mmol} / 1$ (i. e. about the fasting blood glucose concentration) and is not inhibited by the product glucose 6-phosphate, is an adaptive enzyme. Glucokinase activity decreases when rats are starved or fed a carbohydrate-free diet and when made diabetic with alloxan or streptozotocin. Activity is restored by feeding a normal diet or by treatment with insulin, as appropriate. On the basis of this and other evidence, both dietary glucose and insulin appear to be necessary for the synthesis of glucokinase in vivo [1-3].

Species differences in the adaptive behaviour of glucokinase have been reported but there have been conflicting statements concerning the mouse [1, 4-6]. An additional genetic factor or factors was identified in the mouse as a result of a survey of glucokinase activities in various inbred strains, the activities falling into three distinct ranges [7]. Genetic analysis using crosses and back-crosses of a high-activity $(\mathrm{C} 3 \mathrm{H} / \mathrm{HeJ})$ and a lowactivity $(\mathrm{RF} / \mathrm{J})$ strain suggested control by a single codominant gene. Coleman [7] also described the interaction of starvation and diabetes on glucokinase activity in the two strains.
Because of our previous experience with glucokinase [3, 8-11], we decided to confirm or otherwise and expand upon the basic observations previously reported [7] using $\mathrm{C} 3 \mathrm{H} / \mathrm{He}$ and $\mathrm{C} 58$ mice. We then explored the relationship between glucokinase activity and circulating insulin concentrations. The possible physiological significance of different glucokinase activities has also been examined.

\section{Materials and Methods}

\section{Animals}

Pedigree mating pairs of $\mathrm{C} 3 \mathrm{H} / \mathrm{He}$ and $\mathrm{C} 58$ inbred strains of mice were purchased from Bantin and Kingman, Hull, UK, in September 1978 and colonies have subsequently been maintained in our animal house by same-litter sibling mating. The most productive subline of each strain was selected after the third litter in each generation. Experimental animals were subsequently produced by a "trafficlight" scheme [12], and for these studies were taken from the third to the eleventh generation.

Only male mice (aged 8-10 weeks) have been used in the experiments. Unless otherwise stated, they were fed ad libitum on modified rat/mouse breeding diet cubes (Heygate, Northampton, UK). The carbohydrate-free synthetic diet was that of Walker and Eaton [13]. Post-absorptive animals had had food withdrawn $6 \mathrm{~h}$ previously. When mice were starved they were kept in wire-bottomed cages. Diabetes was induced with the indicated dose of streptozotocin (Sigma, St. Louis, USA) freshly-dissolved in $10 \mathrm{mmol} / 1$ sodium citrate buffer (pH 5.0) and injected IP. Injected insulin was insulin zinc suspension lente (Wellcome, London, UK). 
Blood samples were taken into heparinized tubes either after decapitation or by orbital sinus puncture from animals under halothane anaesthesia. Glucose tolerance and insulin-response tests were performed on mice starved overnight $(16 \mathrm{~h})$ and then given $4 \mathrm{~g}$ glucose $/ \mathrm{kg}$ body weight in the form of a $20 \%(\mathrm{w} / \mathrm{v})$ aqueous solution, orally by ball-tipped intubation needle [14].

\section{Analytical Procedures}

Plasma glucose was determined by a glucose oxidase technique (GOD-Perid method, Boehringer, Mannheim, FRG) on 5- $\mu$ l samples using an autoanalyzer.

Plasma immunoreactive insulin was estimated with insulin radioimmunoassay kits (Radiochemical Centre, Amersham, UK) but using mouse insulin (Batch M181072, Novo, Copenhagen, Denmark) as standard. The batch experiments (see later) were performed on $100-\mu \mathrm{l}$ plasma samples and the coefficient of variation was better than $10 \%$. To permit experiments requiring several blood samples from one animal, the standard procedure was reduced to one-quarter size and needed $25-\mu$ l plasma samples and a modified range of standards; similar accuracy was achieved.

Assays of glucokinase and hexokinase activity were performed on the supernatant fraction of liver homogenates by methods employed and evaluated previously $[8,10]$. Because the addition of 6 -phosphogluconate dehydrogenase [15] did not increase further the rate of NADPH production in the coupled assay system, the amount of NADPH formed was halved to give the rate of glucose phosphorylation. One unit of glucokinase activity is that catalysing the phosphorylation of $1 \mu \mathrm{mol}$ of glucose $/ \mathrm{min}$ at $32^{\circ} \mathrm{C}$, and tissue activities are recorded as units per $g$ wet weight of liver.

Protein in the liver supernatant preparations was determined by a Biuret procedure

Results are expressed as mean \pm SEM with the number of observations in parentheses. Significance of differences between means were evaluated by Student's t-test. For genetic analysis of the glucokinase activity data, individual values were grouped by one of two procedures. The first, used by Ciarranello and Axelrod [16], involved determining the cut-off values for high-, low- and intermediate-activity phenotypic classes by plotting normal distribution curves based on the data from the two parental strains and $F_{1}$ hybrids. The second procedure, as used by Gluecksohn-Waelsch et al. [17], involved proportional assignment to each class of results within the overlap regions.

\section{Results}

\section{Genetic Analysis on $\mathrm{C} 3 \mathrm{H} / \mathrm{He}$ and C58 Strains}

These two strains were chosen because they were in the high- and low-glucokinase activity groups of mouse strains described by Coleman [7] and were available in the UK. Fed animals of the parental strains showed about a twofold difference in mean glucokinase activity $(1.99 \pm 0.03$ and $0.93 \pm 0.02$ units $/ g$ of liver for $\mathrm{C} 3 \mathrm{H} / \mathrm{He}$ and C58 strains, respectively, $n=50$ ). The $\mathrm{F}_{1}$ hybrid animals showed an intermediate range of activity $(1.29 \pm$ 0.03 units $/ \mathrm{g}$ of liver, $n=50$ ). In the latter and the other groups of animals described below, reciprocal crosses were made to determine whether any sex-linked factors were involved in the determination of glucokinase activities; no such evidence was found so the results were pooled to provide the data reported.

Because of a small overlap of activities (raw data omitted) between the parental and $F_{1}$ hybrid animals, the activities found in the backcrosses (a total of 50 ani- mals) between $F_{1}$ hybrids and each of the parental strains and in $F_{2}$ hybrids ( 50 animals) were assigned to groups as described in the Materials and Methods section [16]. The numbers of animals in each of the groups of backcrosses did not differ significantly from the predicted ratios of $1: 1$ or in the $F_{2}$ hybrid groups from the predicted ratios of $1: 2: 1(\mathrm{p}>0.50)$. The numbers of animals (total $n=50$ ) in each group showed a slightly improved fit to predicted ratios when the alternative [17] procedure for assignment was used $(p>0.80)$.

\section{Physiological Regulation of Glucokinase Activity}

There was no significant lowering of glucokinase activity in the livers of mice of either strain during starvation when expressed on a per $g$ wet weight basis although there was an absolute decrease due to the fall in liver weight (Table 1). Mice of the C58 strain did not survive starvation for $72 \mathrm{~h}$. When the mice were fed a carbohydrate-free diet glucokinase activity decreased slowly after about 2 days to reach significantly lower figures after 7 days (Table 1). The decrease in the C58 strain was the more dramatic both in the percentage change and in the final value. When animals were fed the carbohydratefree diet for 7 days and then returned to normal diet, the original activity was restored within $24 \mathrm{~h}$ either completely (in the C58 strain) or partially (in the $\mathrm{C} 3 \mathrm{H} / \mathrm{He}$ strain) (Table 1); in the latter case restoration was complete inside $48 \mathrm{~h}$ (results not shown). Plasma glucose concentrations were not changed significantly by these dietary modifications.

Mouse strains vary in their susceptibility towards the diabetogenic drug streptozotocin $[18,19]$. The optimum dose required in our animals was determined in preliminary experiments by assessing the balance between the positive criterion of the proportion of a group of treated animals showing gross glycosuria $48 \mathrm{~h}$ after a single IP injection of streptozotocin, and the negative criterion of the number failing to survive for 5 days. The range of doses tested was $100-400 \mathrm{mg} / \mathrm{kg}$ body weight. The doses that resulted in about $90 \%$ of the animals both being diabetic within $48 \mathrm{~h}$ and surviving the 5 days were 350 and $180 \mathrm{mg} / \mathrm{kg}$ body weight for $\mathrm{C} 3 \mathrm{H} / \mathrm{He}$ and C58 mice, respectively; these doses were used in subsequent experiments.

Glucokinase activities decreased to very low values following injection of streptozotocin (Table 1); the decreases were significant within $48 \mathrm{~h}(\mathrm{p}<0.05$, results not shown). The two strains showed a difference in the amount of insulin required to restore glucokinase activity to normal in mice that had been streptozotocin-diabetic for 7 days. We did not consider it justified to sacrifice the large number of animals that would have been required to establish a precise dose-time course for this restoration. Using only small groups of mice, the quantities of insulin (given as two SC injections/day) necessary to return glucokinase activity to normal within 3-4 days were about 4 and 0.5 units/day in the 
Table 1. Effect of starvation, of carbohydrate-free diet and of streptozotocin-diabetes on glucokinase activity

\begin{tabular}{|c|c|c|c|c|c|}
\hline Mouse strain and physiological status & $\begin{array}{l}\text { Body weight } \\
\text { (g) }\end{array}$ & $\begin{array}{l}\text { Liver weight } \\
\text { (g) }\end{array}$ & $\begin{array}{l}\text { Plasma } \\
\text { glucose } \\
(\mathrm{mmol} / \mathrm{l})\end{array}$ & $\begin{array}{l}\text { Supernatant } \\
\text { protein } \\
\text { (mg/g of liver) }\end{array}$ & $\begin{array}{l}\text { Glucokinase } \\
\text { activity } \\
\text { (units/g of liver) }\end{array}$ \\
\hline \multicolumn{6}{|l|}{$\mathrm{C} 3 \mathrm{H} / \mathrm{He}$} \\
\hline Normal, fed $(n=10)$ & $26.9 \pm 0.8$ & $1.44 \pm 0.04$ & $12.2 \pm 0.3$ & $99 \pm 5$ & $1.99 \pm 0.13$ \\
\hline Starved 48 h $(n=10)$ & $21.4 \pm 1.1$ & $0.88 \pm 0.03$ & $6.9 \pm 0.2$ & $95 \pm 7$ & $1.89 \pm 0.13$ \\
\hline Starved 72 h $(n=10)$ & $19.6 \pm 0.4$ & $0.87 \pm 0.04$ & $5.3 \pm 0.6$ & $96 \pm 4$ & $1.87 \pm 0.07$ \\
\hline Starved 48 h $(n=10)$ & $16.8 \pm 0.4$ & $0.64 \pm 0.03$ & $6.0 \pm 0.8$ & $82 \pm 6$ & $0.96 \pm 0.05$ \\
\hline \multicolumn{6}{|l|}{ Effect of carbohydrate-free diet } \\
\hline \multicolumn{6}{|l|}{$\mathrm{C} 3 \mathrm{H} / \mathrm{He}$} \\
\hline Normal diet $(n=4)$ & $25.0 \pm 1.6$ & $1.32 \pm 0.07$ & $8.7 \pm 0.4$ & $91 \pm 1$ & $2.21 \pm 0.12$ \\
\hline Special diet for 7 days $(n=4)$ & $23.4 \pm 0.6$ & $1.44 \pm 0.05$ & $10.3 \pm 1.1$ & $92 \pm 6$ & $1.12 \pm 0.08$ \\
\hline $\begin{array}{l}\text { Special diet for } 7 \text { days re-fed normal diet } \\
\text { for } 1 \text { day }(n=4)\end{array}$ & $22.5 \pm 0.7$ & $1.03 \pm 0.05$ & $8.7 \pm 1.2$ & $80 \pm 2$ & $1.05 \pm 0.04$ \\
\hline \multicolumn{6}{|l|}{ Effect of insulin } \\
\hline \multicolumn{6}{|l|}{$\mathrm{C} 3 \mathrm{H} / \mathrm{He}$} \\
\hline Normal $(n=8)$ & $27.4 \pm 1.0$ & $1.48 \pm 0.05$ & $11.8 \pm 0.7$ & $76 \pm 6$ & $1.92 \pm 0.09$ \\
\hline \multicolumn{6}{|l|}{ Streptozotocin diabetic } \\
\hline for 3 days $(n=4)$ & $27.0 \pm 1.6$ & $1.31 \pm 0.12$ & high $^{\mathrm{a}}$ & $60 \pm 7$ & $0.62 \pm 0.05$ \\
\hline for 7 days $(n=6)$ & $21.2 \pm 0.7$ & $1.17 \pm 0.05$ & high $^{\mathrm{a}}$ & $70 \pm 5$ & $0.10 \pm 0.03$ \\
\hline \multicolumn{6}{|l|}{$\mathrm{C} 58$} \\
\hline Normal $(n=8)$ & $23.1 \pm 0.9$ & $1.08 \pm 0.04$ & $9.3 \pm 0.5$ & $63 \pm 6$ & $0.85 \pm 0.04$ \\
\hline \multicolumn{6}{|l|}{ Streptozotocin-diabetic } \\
\hline for 3 days $(n=4)$ & $20.0 \pm 0.3$ & $0.89 \pm 0.01$ & $\operatorname{high}^{\mathrm{a}}$ & $96 \pm 3$ & $0.18 \pm 0.03$ \\
\hline
\end{tabular}

Results expressed as mean \pm SEM. ${ }^{a}>56 \mathrm{mmol} / \mathrm{l}$

$\mathrm{C} 3 \mathrm{H} / \mathrm{He}$ and $\mathrm{C} 58$ mice, respectively; this difference was very clear. At the same time, these dosages brought the plasma glucose concentrations close to normal range.

No significant changes in hexokinase activity were observed during any of the above experiments.

\section{Circulating Insulin Concentrations under Various Conditions}

Coleman [7] reported no difference in plasma immunoreactive insulin in his $\mathrm{C} 3 \mathrm{H} / \mathrm{HeJ}$ and $\mathrm{RF} / \mathrm{J}$ strains, but the physiological conditions of sampling were not specified. Determinations of circulating insulin concentrations in our high-and low-glucokinase activity strains in the fed and starved states and after streptozotocin treatment indicated not only that there were changes within one strain but that, in most situations, the concentrations in the $\mathrm{C} 3 \mathrm{H} / \mathrm{He}$ strain were significantly higher than in the C58 strain $(p<0.01)$. Because these results (not presented in detail) were based upon blood samples obtained from batches of animals and assayed at various times, they were confirmed by taking serial blood samples from the same mice from another group of animals. Mice were bled by orbital sinus puncture af- ter feeding and then $6 \mathrm{~h}$ (post-absorptive) and $48 \mathrm{~h}$ after removal of food. After a rest period on normal diet the carbohydrate-free diet was fed for 7 days and further blood samples taken. After a further rest period on normal diet the same animals were made streptozotocindiabetic and further samples obtained. The data obtained in this way (Table 2) were remarkably consistent with those from the batch blood samples. The general picture that emerged was of higher circulating concentrations of insulin in the $\mathrm{C} 3 \mathrm{H} / \mathrm{He}$ strain than in the $\mathrm{C} 58$ under most circumstances. The only exceptional result recorded in Table 2 was the decrease in post-absorptive plasma insulin concentration seen in $\mathrm{C} 3 \mathrm{H} / \mathrm{He}$ mice but not in C58 mice that had been fed a carbohydrate-free diet. For comparison, some data are included (Table 2) on $\mathrm{BALB} / \mathrm{c}$ mice, a strain that has intermediate [7] glucokinase activity (in fed animals: $1.63 \pm 0.04$ units $/ \mathrm{g}$ wet weight of liver, $n=6$ ).

\section{Glucose Tolerance and Insulin Response to Glucose Load}

Many cellular phenomena, both hepatic and non-hepatic, contribute to glucose tolerance so that a difference in glucokinase activity is not the only factor determining the fate of a glucose load. Nevertheless, in view 
Table 2. Plasma insulin concentrations in the same male mice under vatious conditions

\begin{tabular}{lllll}
\hline Physiological status & \multicolumn{2}{l}{ Insulin $^{a}(\mathrm{ng} / \mathrm{ml}$ plasma) in each mouse strain } & \\
\cline { 2 - 5 } & $\mathrm{C} 3 \mathrm{H} / \mathrm{He}$ mice & C58 mice & F $_{1}(\mathrm{C} 3 \mathrm{H} / \mathrm{He} \times \mathrm{C} 58)$ mice & BALB/c mice \\
\hline Fed & $3.49 \pm 0.65(18)$ & $1.79 \pm 0.38(18)$ & $2.00 \pm 0.29(18)$ & $2.36 \pm 0.27(6)$ \\
Post-absorptive & $1.60 \pm 0.31(18)$ & $0.89 \pm 0.22(20)$ & $0.95 \pm 0.22(18)$ & $1.04 \pm 0.20(5)$ \\
Starved 48 h & $1.10 \pm 0.28(10)$ & $0.57 \pm 0.16(8)$ & $0.85 \pm 0.18(14)$ & $0.91 \pm 0.19(5)$ \\
Carbohydrate-free dietc, fed & $1.65 \pm 0.15(11)$ & $1.04 \pm 0.22(14)$ & $1.37 \pm 0.20(16)$ & - \\
Carbohydrate-free, post-absorptive & $0.69 \pm 0.20(11)$ & $0.91 \pm 0.21(14)$ & $1.03 \pm 0.18(16)$ & - \\
Streptozotocin-diabetic ${ }^{\mathrm{d}}$, fed & $2.10 \pm 0.38(7)$ & $0.72 \pm 0.10(7)$ & - & - \\
Streptozotocin-diabetic, post-absorptive & $1.16 \pm 0.13(7)$ & $0.37 \pm 0.11(7)$ & - & - \\
\hline
\end{tabular}

Results expressed as mean \pm SEM with number of mice in parantheses. ${ }^{2}$ Estimations were performed on $25-\mu 1$ samples of plasma prepared from blood obtained by orbital sinus puncture from the same groups of animals; ${ }^{b}$ hybrids included an equal number of animals obtained by reciprocal matings; ${ }^{c}$ mice were fed the diet ad libitum for 7 days; ${ }^{d}$ for doses of streptozotocin used, see text; animals were killed 5 days after treatment
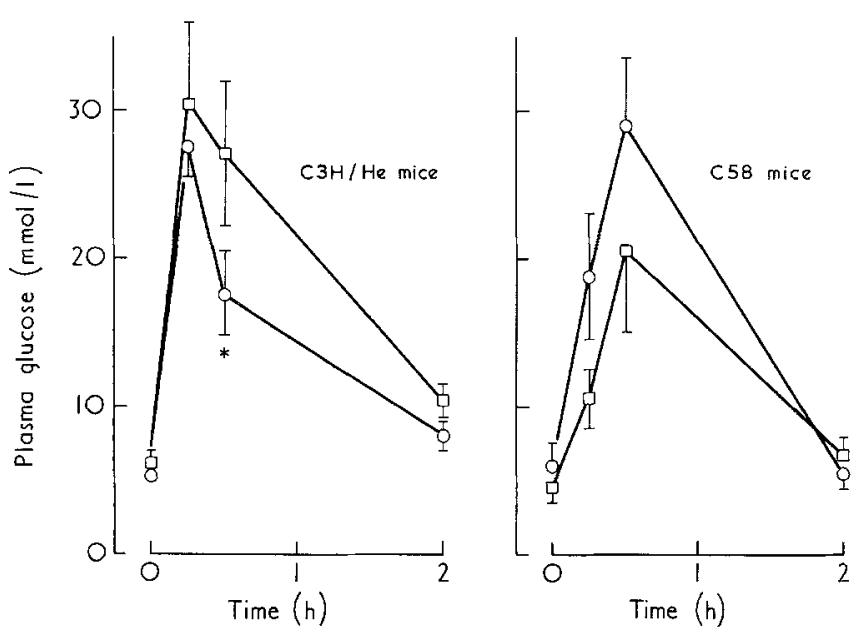

Fig. 1. Glucose tolerance tests. Animals were given an oral glucose load ( $4 \mathrm{~g} / \mathrm{kg}$ body weight) at zero time. Points and vertical bars represent the mean \pm SEM of from six to ten separate samples. Significance of difference: $* p<0.05$. Key: $\bigcirc-0$ : animals previously fed normal diet; $\square-\square$ : animals previously fed carbohydrate-free diet for 7 days
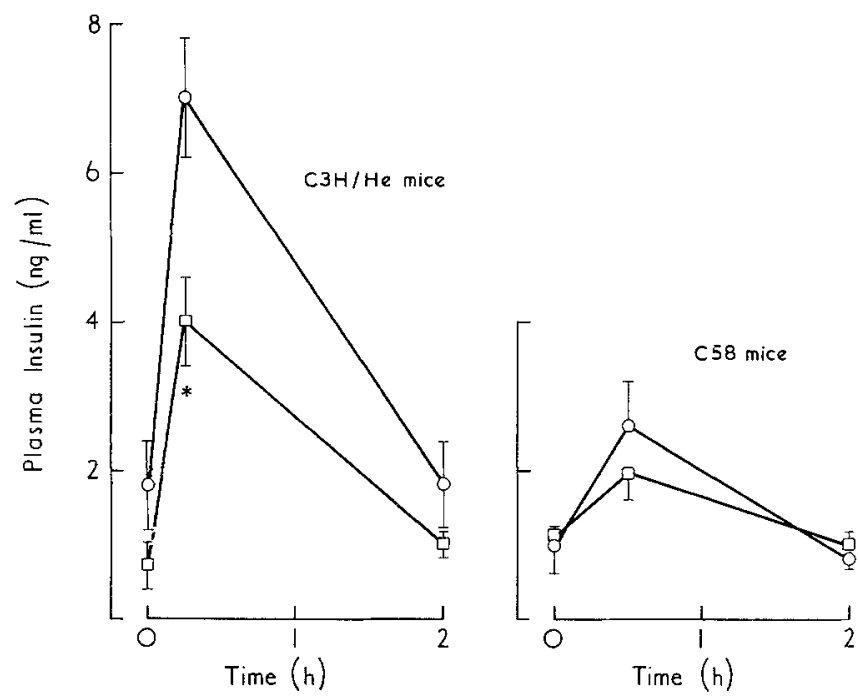

Fig. 2. Insulin response to glucose load. The response is in the same animals as in Fig. 1 which were given an oral glucose load $(4 \mathrm{~g} / \mathrm{kg}$ body weight) at zero time of the activity differences between the two strains of mice reported above, simple glucose tolerance tests and measurements of insulin response were performed to reveal any major differences between the strains. The experiments possible were severely restricted by the quantity of blood obtainable from mice when animal survival and multiple samples are required. As more plasma $(25 \mu \mathrm{l})$ is required for the scaled-down insulin assay than for a glucose determination $(5 \mu \mathrm{l})$, only three samples large enough for insulin measurements were taken; these were at zero time and $2 \mathrm{~h}$ later, with the third at either $15 \mathrm{~min}(\mathrm{C} 3 \mathrm{H} / \mathrm{He}$ mice $)$ or $30 \mathrm{~min}$ (C58 mice) after glucose administration, corresponding to the peaks of the respective glucose tolerance curves.

The results show that, despite the comparatively large oral glucose load ( $4 \mathrm{~g} / \mathrm{kg}$ body weight) given, plasma glucose and plasma immunoreactive insulin concentrations returned essentially to 16-h-starved values within $2 \mathrm{~h}$ (Figs. 1 and 2). Peak plasma glucose values were recorded at $15 \mathrm{~min}$ for $\mathrm{C} 3 \mathrm{H} / \mathrm{He}$ mice and at 30 min for C58 mice (Fig. 1), but the magnitudes of the peaks were not significantly different between the two strains. The marked difference between the strains in plasma insulin concentrations was confirmed (Fig. 2); a few determinations on samples at $15 \mathrm{~min}$ from C58 mice did not suggest an earlier peak in the insulin data. In the $\mathrm{C} 3 \mathrm{H} / \mathrm{He}$ mice the improved glucose tolerance at $30 \mathrm{~min}$ (Fig. 1) found in animals previously fed normal diet when compared with those fed the carbohydratefree diet may be due to the significantly greater insulin release at $15 \mathrm{~min}$ (Fig. 2). In general, the lower circulating insulin concentrations in the C58 mice (Table 2) are reflected in the comparatively small response to large glucose load (Fig. 2).

\section{Discussion}

Finding no differences in heat inactivation of the glucokinase in his mouse strains $(\mathrm{C} 3 \mathrm{H} / \mathrm{HeJ}$ and $\mathrm{RF} / \mathrm{J})$, Coleman [7] concluded tentatively that the enzyme was the same structurally in these strains. In our own investiga- 
tions on the partially-purified enzyme from $\mathrm{C} 3 \mathrm{H} / \mathrm{He}$ and $\mathrm{C} 58$ mice by both kinetic and immunological procedures (unpublished observations), we have also found no differences. Thus it remains most likely that the molecular basis of the activity data resides in genetic control at a non-structural gene locus.

Where comparable, the data in Table 1 are similar to the results of Coleman [7]. Why the glucokinase activity (per g liver) does not decrease on starvation (especially after 3 days in the $\mathrm{C} 3 \mathrm{H} / \mathrm{He}$ animals) but does so slowly on feeding a carbohydrate-free diet is not apparent, especially as plasma insulin concentrations are lower after starvation for 2 days than after feeding the special diet for 7 days (Table 2). The question arises as to whether the differences in glucokinase activities in the two strains bear a relationship to the differences in the circulating insulin concentrations. The results certainly extend previous observations that mouse strains vary in susceptibility to diabetogenic drugs and also to insulin $[7,18,19,28]$.

How insulin regulates protein synthesis in a tissue such as liver remains largely unknown. The apparent role of insulin in glucokinase synthesis represents a fairly specific effect in that the activity of very many other enzymes is unaffected. It is therefore relevant that insulin can in some way control the amount of specific mRNA in liver coding for exported proteins such as albumin [20] and $\alpha_{2 u}$-globulin [21] or for endogenous adaptive enzymes such as tyrosine aminotransferase [22] and phosphoenolpyruvate carboxykinase [23, 24]. The variations in concentration of pyruvatekinase mRNA with diet [23] may be affected via insulin. Effects of insulin upon messenger translatability [22] or the machinery of protein synthesis [24] are known. These considerations indicate a clear need to assess the binding of insulin to liver plasma membranes and the amounts of translatable mRNA for glucokinase in the livers of the two mouse strains.

Enzyme degradation rates may also be different in the high- and low-activity strains. The data in Table 2 are insufficient to determine this. The general impression is that the turnover of glucokinase may be slower in the mouse than in the rat $[2,27]$.

Like the low-activity RF/J strain [7], animals of the C58 strain do not survive starvation for 3 days but the reason for this need not be anything to do with hepatic glucokinase or carbohydrate metabolism. Some small differences between the strains in terms of glucose tolerance and insulin response to a glucose load are seen in Figures 1 and 2 but these do not seem to be large enough to suggest a major disadvantage in C58 strain because, under normal circumstances, glucokinase activity is only half that in the $\mathrm{C} 3 \mathrm{H} / \mathrm{He}$ strain. Insulin sensitivity is nevertheless the basic difference between the strains in that the plasma glucose concentration patterns (Table 1) are not significantly different although the plasma insulin concentrations are. However, there could be compensatory changes in antagonistic hor- mones such as glucagon and corticosteroids. Many more metabolic variables need to be explored in the two strains before a complete understanding of both the cause and significance of the differing glucokinase activities can be elucidated.

Acknowledgements. We thank the British Diabetic Association for support of this work and the Medical Research Council (UK) for a Training Studentship to P. A. James.

\section{References}

1. Weinhouse S (1976) Regulation of glucokinase in liver. Curr Top Cell Regul 11: 1-50

2. Niemeyer H, Ureta T, Clark-Turri C (1975) Adaptive behaviour of liver glucokinase. Mol Cell Biochem 6: 109-126

3. Wakelam MJO, Walker DG (1981) The separate roles of glucose and insulin in the induction of glucokinase in hepatocytes isolated from neonatal rats. Biochem J 196: 383-390

4. Lauris V, Cahill GF (1966) Hepatic glucose phosphotransferases. Variations among species. Diabetes 15: 475 479

5. Ureta T, Gonzalez C, Lillo S, Niemeyer H (1971) Comparative studies on glucose phosphorylating isoenzymes of vertebrates. -1 . The influence of fasting and the nature of the diet on liver glucokinase and hexokinases of rodents. Comp Biochem Physiol 40B: $71-80$

6. Yen TT, Stamm NB (1981) Constitutive hepatic glucokinase in $\mathrm{db} / \mathrm{db}$ and $\mathrm{ob} / \mathrm{ob}$ mice. Biochim Biophys Acta 657: 195-202

7. Coleman DL (1977) Genetic control of glucokinase activity in mice. Biochem Genet 15:297-305

8. Walker DG, Rao S (1964) The role of glucokinase in the phosphorylation of glucose by rat liver. Biochem $\mathrm{J} 90: 360-368$

9. Holroyde MJ, Allen MB, Storer AC, Warsy AS, Chesher JME, Trayer IP, Cornish-Bowden A, Walker DG (1976) The purification in high yield and characterization of rat hepatic glucokinase. Biochem J 153: 363-373

10. Wakelam MJO, Aragon C, Gimenez C, Allen MB, Walker DG (1979) Thyroid hormones and the precocious induction of hepatic glucokinase in the neonatal rat. Eur J Biochem 100:467-475

11. Wakelam MJO, Allen MB, Walker DG (1980) Factors that prevent the premature appearance of glucokinase in neonatal rat liver. Biochem J 186: 817-826

12. Lane-Petter W (1961) Provision of laboratory animals for research. A practical guide. Elsevier, Amsterdam

13. Walker DG, Eaton SW (1967) Regulation of development of hepatic glucokinase in the neonatal rat by the diet. Biochem J 105: 771-777

14. Miller SA, Dymsza HA (1963) Artificial feeding of neonatal rats. Science 141: $517-518$

15. Storer AC, Cornish-Bowden A (1974) The kinetics of coupled enzyme reactions. Applications to the assay of glucokinase, with glucose 6-phosphate dehydrogenase as coupling enzyme. Biochem J 141: 205-209

16. Ciaranello RD, Axelrod J (1973) Genetically controlled alterations in the rate of degradation of phenylethanolamine $\mathrm{N}$-methyltransferase. J Biol Chem 248: 5616-5623

17. Gluecksohn-Waelsch S, Greengard P, Quinn GP, Teicher LS (1967) Genetic variations of an oxidase in mammals. J Biol Chem 242: 1271-1273

18. Rossini AA, Appel MC, Williams RM, Like AA (1977) Genetic influence of the streptozotocin-induced insulitis and hyperglycemia. Diabetes 26: 916-920

19. Cohn JA, Cerami A (1979) The influence of genetic background on the susceptibility of mice to diabetes induced by alloxan and on recovery from alloxan diabetes. Diabetologia 17: 187-191

20. Jefferson LS (1980) Role of insulin in the regulation of protein synthesis. Diabetes 29: 487-496 
21. Roy AK, Chatterjee B, Prasad MSK, Unakar NJ (1980) Role of insulin in the regulation of hepatic messenger RNA for $\alpha_{24}$-globulin in diabetic rats. J Biol Chem 255: 11614-11618

22. Hill RE, Lee K-L, Kenney FT (1981) Effects of insulin on messenger RNA activities in rat liver. J Biol Chem 256: 1510-1513

23. Faliks D, Cohen H, Glaser G, Reshef L (1980) Cycloheximide and pactamycin inhibit the rapid decrease in translatable mRNA activity of P-enolpyruvate carboxykinase. FEBS Lett 109: 112-116

24. Andreone, TL, Beale EG, Bar RS, Granner DK (1982) Insulin decreases phosphoenolpyruvate carboxykinase mRNA activity by a receptor-mediated process. J Biol Chem 257: 35-38

25. Cladaras C, Cottam GL (1980) Dietary alteration of translatable mRNA sequences coding for liver pyruvate kinase. $\mathrm{J}$ Biol Chem 255: 11499-11503

26. Pilkis SJ, Korner A (1971) Effect of diabetes and insulin treatment on protein synthetic activity of rat liver ribosomes. Biochim Biophys Acta $247: 597-608$
27. Sibrowski W, Müller MJ, Seitz HJ (1981) Effect of different thyroid states on rat liver glucokinase synthesis and degradation in vivo. J Biol Chem 256: 9490-9494

28. Stauffacher W, Orci L, Cameron DP, Burr IM, Renold AE (1971) Spontaneous hyperglycaemia and/or obesity in laboratory rodents: an example of the possible usefulness of animal disease models with both genetic and environmental components. Rec Prog Horm Res 27: 41-95

Received: 9 December 1982

and in revised form: 13 April 1983

Professor D. G. Walker

Department of Biochemistry

The University of Birmingham

Edgbaston

Birmingham B15 2TT, UK 